\title{
Geographic Information Systems Used as a Practical Way of Teaching Mathematics
}

\author{
Sandro Laudares, João Bosco Laudares, Matheus Pereira Libório \\ Department of Geography, Catholic University of Minas Gerais, Belo Horizonte, Brazil \\ Email: sandrolaudares@gmail.com
}

How to cite this paper: Laudares, S., Laudares, J.B. and Libório, M.P. (2016) Geographic Information Systems Used as a Practical Way of Teaching Mathematics. Journal of Geographic Information System, 8, 608-617.

http://dx.doi.org/10.4236/jgis.2016.85050

Received: September 13, 2016

Accepted: October 28, 2016

Published: October 31, 2016

Copyright $\odot 2016$ by authors and Scientific Research Publishing Inc. This work is licensed under the Creative Commons Attribution International License (CC BY 4.0).

http://creativecommons.org/licenses/by/4.0/

\begin{abstract}
This paper presents reflections on proposals to merge Mathematics and Geography when teaching undergraduates from inter- and trans-disciplinary spatial models using mathematical modeling to enable spatial analysis and visualization through GIS-Geographic Information Systems. It brings forward an approach to Geography with new technologies integrating it with Statistics and Computer Science among other subjects. Thus, it describes some practical cases that are examples of geographical problems solved mathematically. The results show that GIS can be an educational tool for teaching both Geography and Mathematics.
\end{abstract}

\section{Keywords}

Geotechnology, Geography, Mathematical Modeling, Geographic Tools, Teaching

\section{Introduction}

There is an effective intersection of Mathematics with its quantitative methods and Geography, as evidenced in [1], in the need for spatial analysis, represented in [2]. Thus, Geography appears to have intersections with areas such as education (demonstrated by [3] and [4]); statistics and computer science, presented by [5]; economics exposed in [6]; physics as in the work of [7]; sociology according to [8]; and among other disciplines as is possible to perceive in [9], especially, using methods such as the measure between points with quantitative resources facilitated by the use of Statistics and Mathematics, which is possible to find in [10]. These methods are been disseminated in society, but also in technology and science explored by [11] [12] in their work. Its scientific essence is added to the mathematizing with the modeling processes in a qualitative form as [13] reflects and quantitative (observed in [2] [14]) approaches.

The usage of geoprocessing in Geography has been recurring in environmental anal- 
ysis and demonstrated recently, through the work of [15] and [16]. These works have shown how geographic databases can be managed and accessed by many users (state power, researchers and other institutions) and, through the treatment of spatial information, it generates knowledge that contributes to a more rational decision making process. Figure 1 illustrates the intersection of Geography and Mathematics as analytical geography enabled by GIS-Geographic Information Systems, as stated by [17].

Thus, in essentially geographic areas where almost everything needs measuring, in order to get optimal results organizations build up strategies and processes associated to the geographical space. In spatial visualization, the measure is a mathematical approach essential to digital resources; [18] treats this measure sense as spatial abilities for mathematics education. This paper presents practical examples of "geographical" problems that have solved mathematically.

Geotechnology is available in very wide proportions. So that, as stated by [19], the U.S. Department of Labor has designated Geo-technology as one of the three "megatechnologies" of the 21 st century as the result of the general wave of computer pervasiveness in modern society [19]. This concept expects that information must be just a click away and spatial information is no exclusive, emphatically [20] briefly exposed a "geotechnological" probable future.

The geographic visualization is a discipline emerging from cartographic principles in visualization and the development of maps, exploring spatial visualization ([21] shows more). This scientific visualization method has the potential to provide new ways into the complexity of phenomena as decision-making, and education, as a knowledge construction and decision support process, which is discussed in [22].

The so called geovisual analytics is an interdisciplinary field that integrates information and geovisualization used to support geospatial intelligence, being possible to use as the crisis management example [23] worked on generating insights about spatialtemporal and uncertain information (see [24]).

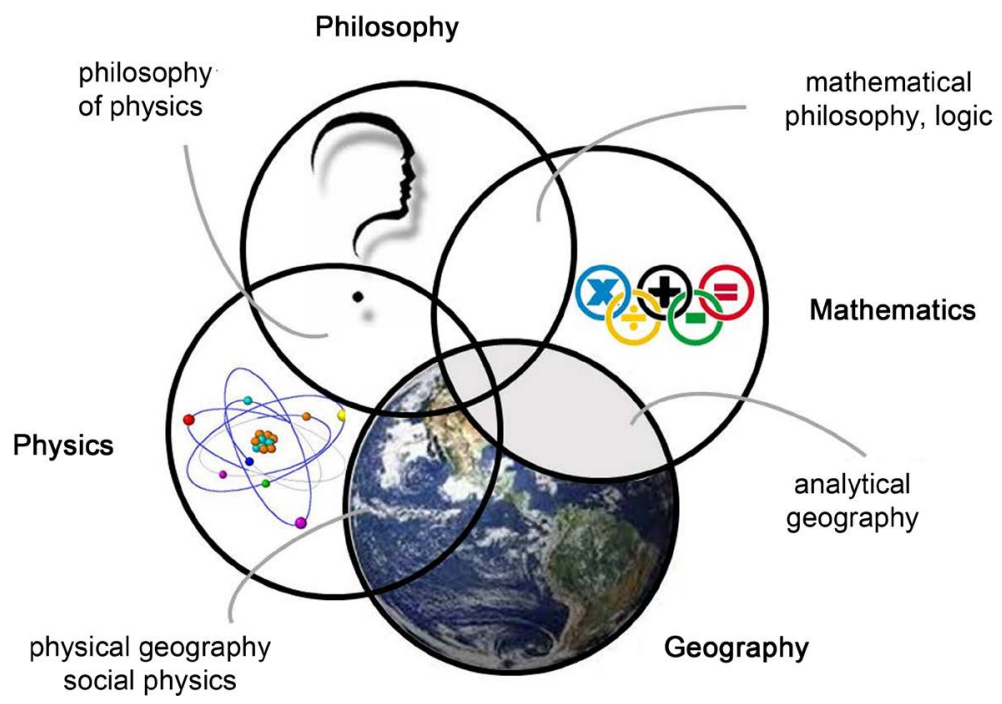

Figure 1. Geography and Mathematics intersection adapted from [18]. 
Geographic Information Systems (GIS) are programs, which connect math, science and social science concepts with a large number of resources for teachers to provide an integrate activities with math and science. [25] presented as an argument a stand for teacher education founding in the mathematics and science integration. The WebGIS allows visual interaction by geoscientists combining the easy access to data to a visual presentation and the ambit of WebGIS applications are deeper discussed in [26]. It describes the collection and maintenance of geospatial information creating an interactive and dynamic environment, guiding and assisting the users in solving geospatial analysis problems, and it is possible to perceive it through [27].

\section{Methodology}

The main goal of this work is to demonstrate the feasibility of teaching mathematics and geography from practical and visual examples demonstrated in interactive software such as Google Maps and Google Earth. Thus, gathering examples that could be easily understood by the students. In order to clarify the activities developed in this research, Figure 2 illustrates the steps done.

On step 4 the examples created in this research shall give an impression of how using GIS (Geographic Information Systems) could change the conventions of teaching math. This new form of presentation of expert information has spawned new trends. This paper brings forward some related work to compare on how other researches discuss this problem and which is the importance of this subject.

\subsection{New Technologies in Geography}

Nowadays the organizations have sought results through strategic planning facilitated by understanding the visualization of events and points of interest and its geographic location, thus enabling processes such as paths planning and logistics for example. Competitive intelligence and innovation using geotechnologies are bringing good

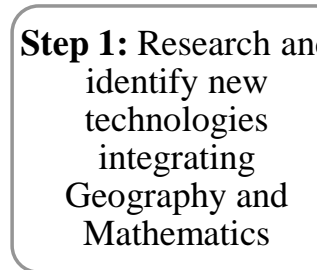

Step 4: Present the results analysis and conclusions of research

Figure 2. Step by step work flow.
Step 2: Study association between mathematical modeling and spatial analysis

Step 3: Select some case studies that demonstrate the need of mathematical modeling to solve geographic problems 
results and when the decision maker understands its insertion in the geographic space, identifying customers and society's needs it enables better decisions. The geographical territory has variables that can be decisive in the municipal government for example. Where to build a new health center? Where to invest? Which streets are in need to fix? Where are the opportunities for a better service to the citizen? These are questions asked daily by entrepreneurs and public administrators.

Thus, geographic technology appears as a tool to analysis and applications to be used in management and planning, allowing a better distribution of resources and targeting efforts. The visualization of the results can be implemented in the form of thematic maps on the Internet, using software components that implement various clustering methods for example. In order to face the technological advances increasingly, society will tend to use the new technologies and include up digitally. The Internet has provided the quickest access to information in the last decade, producing pages, blogs, social networks and thousands of web applications.

Google has become a reference in recent years. After the development and launch of its search engine, several other services were launched integrating a package of immense possibilities for users and developers. Google allows the visualization of interactive digital maps through its Google Maps service. This service allows the inclusion of custom maps in to websites, blogs and web applications through the Google Maps APIApplication Programming Interface. Thus, more and more sites include Google Maps in their content with many different purposes. From simple location of commercial establishments to the use on mobile devices aggregating different functions starting from geocoding and routes generation to optimized decision-making processes such as the ones represented in [22].

There is no doubt that this new form of presentation of spatial information represents new trends. The so called geographical information science is a "meta" science: it is not about the geographical world, it is about information about the geographical world.

\subsection{Geography and Mathematical Modeling}

Mathematical modeling is strongly associated with spatial analysis and visualization specially enhanced with the use of computer resources. In Geography, most innovations related to information technology had its beginnings in the middle of the last century, because at that time there were developed relevant studies based on Mathematics and Statistics models [28]. The execution of those models was possible through the availability of data from satellites. From this integration related to the use of spatial analysis capabilities arise spatial organization features with significant potential within Geography. The "Theoretical-quantitative Geography" brings the geographical studies incorporated into computer programs to perform quantitative spatial analysis implementing complex mathematical models. Thus solving a real problem with geographical spatial analysis manipulated by geovisualization brings the need to build an abstract model referred to a mathematical model for quantitative resolution, as shown in Fig- 
ure 3.

Currently, the resolution of any real problem through spatial analysis needs to use an abstract model that leads us to a mathematical model addressing problem solving. That approach, ultimately, applies to the solution of the real problem, manipulating data with spatial visualization techniques and methods.

Mathematical and statistical concepts and methods approaching geographical related problems in the study of geography are frequently used [29]. Mathematical models enable the representation of the formal perspective on space and time. Euclidean space for example is an abstraction of people's experience with the spatial properties of a place. It deals with points, lines, areas, and volumes, which have intuitive interpretations in the spatial representation. As stated by [18], "Euclidean space is also an instance of a metric space, that is, a space in which the notion of distance between two points and its properties are axiomatically defined and quantifiable" [18].

According to [19], mathematics comes from the needs to count and measure to understand and explain the nature, technical, social, economic and geographic phenomena. Thus, the mathematical knowledge formalized and deductive, within the conceptual framework of science, can facilitate solutions to study problems extracted from concrete situations through the use of technology. The analysis of mathematical models as the basis of web and mobile applications, especially those regarding geographic space demonstrate the need of quantitative as well as qualitative analysis of a phenomenon. Observe, describe, analyze and measure essentially constitute scientific actions, which in its synthesis is a mathematization of reality. Artifacts are tools for more efficient physical intervention process in nature and the environment. Initially mental development was reversed in practice by forming and adjustment from the work activity and the accumulation of experience, which was called empiricism. Now the science and procedural optimization take place before the operating concreteness, thanks to mathematical and computational modeling, says [30].

The next topic presents some case studies implemented through geographic visuali-

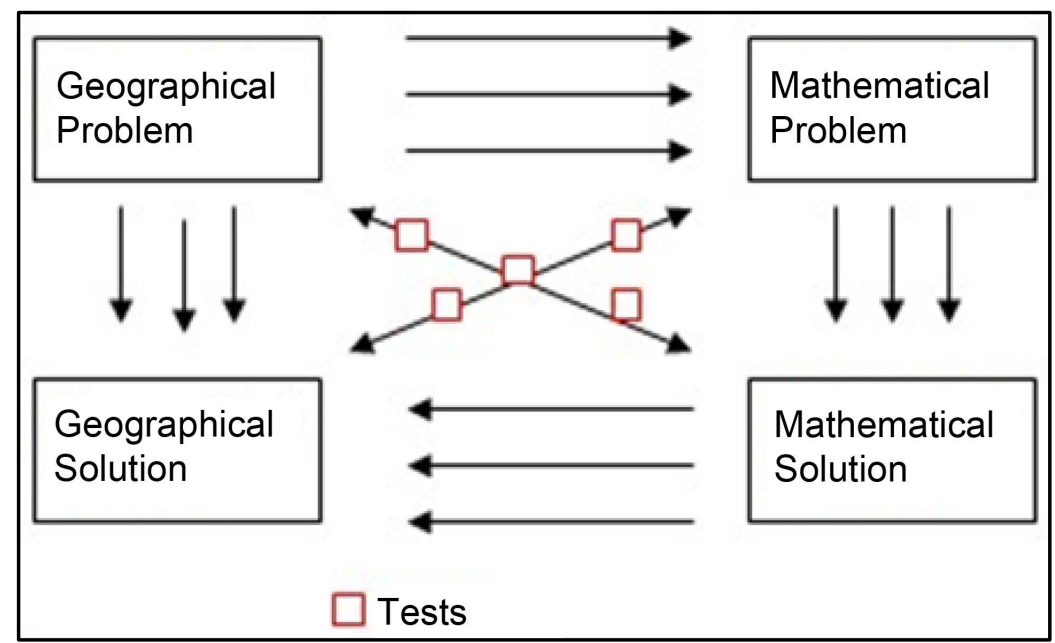

Figure 3. From a Geographical problem to the Geographical solution from [29]. 
zation techniques which allow the visual representation from the retrieval of information in large databases. The complete description of each example is available at the website developed by the authors.

\subsection{Some Case Studies}

Geographic tools nowadays transform society by the increasing use of new technologies like GPS (Global Positioning System) and GIS (Geographic Information Systems) available through the Web and accessed via smart-phones. Today these technologies are available to ordinary people, who can view their home surroundings, the location of events and points of interest, or even route planning. Concerning education, many times students do not understand the necessity of mathematical activities unless they are able to see practical use of those activities. For example, if there were a specific chapter dealing with the properties of polynomial functions it would be more understandable for most students to associate this with the course of a street and actually see that street using a tool like Google Maps.

This work is based on a research about solving mathematics problems using a geographic approach from mathematics models implemented through the Google Maps API (Application Programming Interface), leading to interactive solutions to daily problems that can be solved by web applications or mobile apps. The result was the selection of some applications such as the examples below.

\subsubsection{Using Angles to Implement Sectors Which Contain Points of Interest}

This example demonstrates practical use of angles to generate sectors and select points within target antennas sight. In this case study it was developed a web map demonstrating the use of angles and distance to target antennas sights interactively. The students can see and understand in a visual and interactive way how distance and sector angle impacts on the area covered by the antenna sight, thus selecting different points of interest. Figure 4 shows the resulting prototype.

\subsubsection{Telecommunications Network Planning}

To approach the same problem of network planning and management at PRODEMGE-a data processing and telecommunication company of Minas Gerais, in Brazil, it was necessary to verify altimetry information of several addresses to avoid radio signal jamming. In order to help in this project it was projected and implemented a prototype to simulate antennas sight and plan the best places to install new antenna towers. In order to demonstrate the use of this prototype, which was developed from a terrain digital model available from Google Maps web services it can be accessed from [32].

\subsubsection{Other Studies}

Using a distance matrix and route generating web service from a set of points located within a city or state to identify a better place to allocate a distribution center is another example. The case study resulting prototype is available at the address http://www.3geolink.com/prodemge/rotas7.html. 


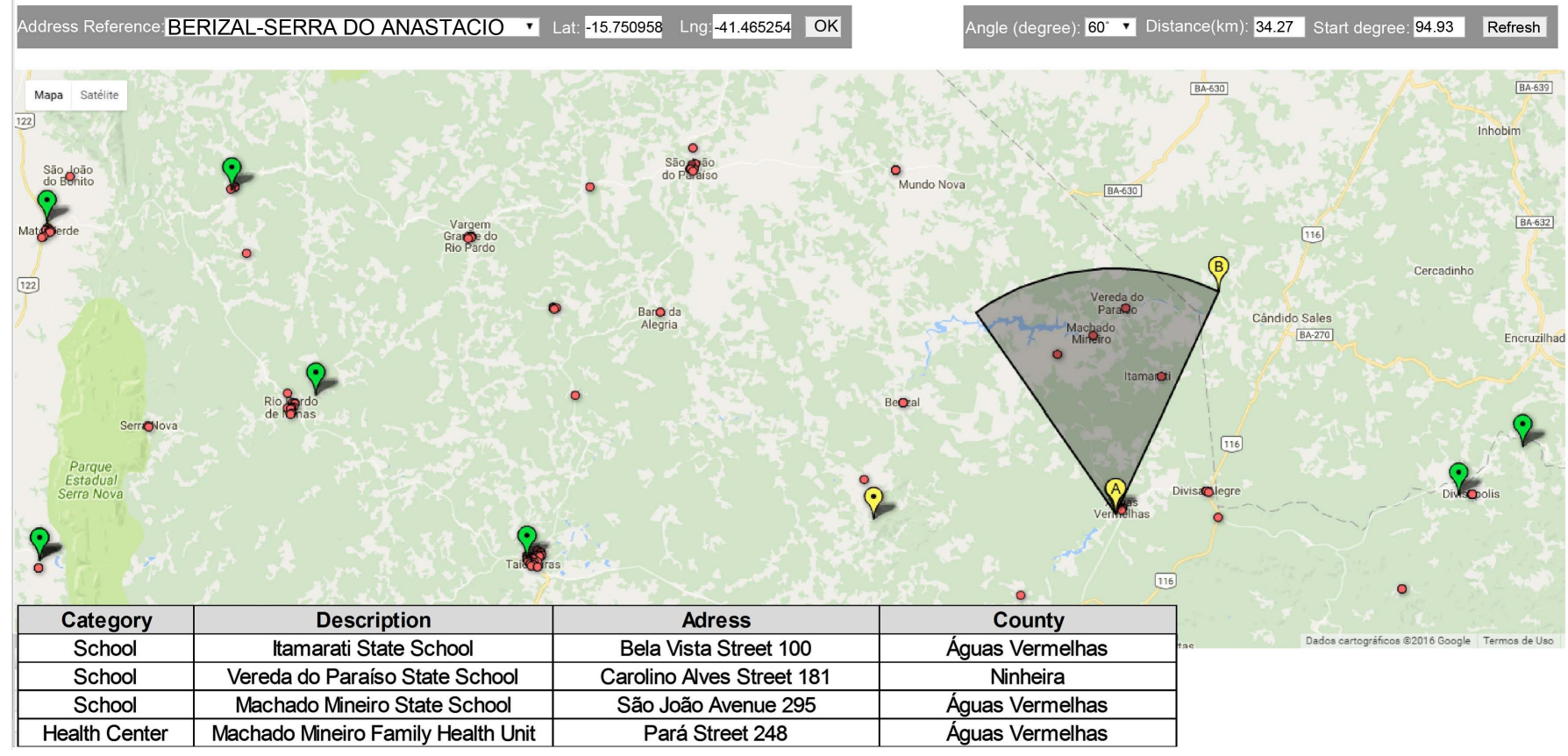

Figure 4. Practical use of angles and distance to plan target radio antennas sight [31].

Identifying points within polygons to solve problems such as finding patients within an influence area of a hospital, thus enabling NHS-Network Health Services to be geographic located illustrates other practical approach The resulting prototype is available at http://www.3geolink.com/hospitalinfluence/.

Other example used to outline distance matrix usage was demonstrated by a web application used to calculate the distance and to generate routes and shortest path between two addresses. The practical solution derived from this method is available at http://www.3geolink.com/estradareal/. Each example demonstrates how to visualize and solve real problems. These solutions are web applications developed from web services which are available through the Google Maps API.

\section{Discussion}

All these examples allow the student to see and understand the need and power of mathematical modelling to enable geographic visualizations and spatial analysis. Although every case is implicitly obtained from mathematical models and implemented as computational solutions. Basic concepts and functions like distance calculating and the use of angles demonstrated in a practical and easy to use way that inspire the student to learn about the formulas used and understand the need of mathematics to solve real problems. Once the teacher shows the student the distance formula and demonstrates a practical and useful way of measuring distances such as in [31], the student will in learning how it was done will be evident.

This research includes other exercises based on related work such as lessons teaching students how to use longitude and latitude to locate various cities, regions, landforms and resources. Initially students identify the boundaries of the school district. Then, 
they are stimulated to navigate through all the streets of their neighborhood through Google Maps. Finally, they perform exercises using Google My Maps service [33], including questions like:

- FIND YOUR SCHOOL ON THE MAP. WHAT IS THE DISTANCE FROM YOUR LOCATION TO THE SCHOOL

- WHICH STREETS INTERCEPT THE SCHOOL? DRAW A POLYGON SURROUNDING THE SCHOOL

- WHICH ARE THE POINTS OF REFERENCE OF YOUR NEIGHBORHOOD?

- WHAT ARE THE GEOGRAPHICAL COORDINATES OF POINTS OF REFERENCE OF YOUR NEIGHBORHOOD?

Through this workshop is held automated image georeferencing and the students check the results in real time using geovisualiztion components, mobile computing and positioning and navigation systems. The spatial characterization also demonstrated the importance of graphical representations in dealing with the dynamics of the city, reinforcing the role of geovisualization in the representation and communication. In many ways, the use of images offers a more vivid representation of mathematics and other sciences. Another important aspect of such activities is to model and design animation prototypes using dynamic Google Maps services available through APIs-application programming interfaces-such as the Google Maps API. The study of 3D animations dealing with geographic aspects and implemented from mathematical models could an interesting point for further investigations.

\section{Conclusion}

The results of this study demonstrate that geographic technologies can be used as educational methods for teaching mathematics. However, it is not enough to just use applications for "smart-phones" and spatial visualization techniques isolated. The integration of these tools and techniques with a methodology that enables an active and constant participation of the students, which can make them able to realize the applicability of mathematics in solving real problems related to geographical space, is required by any school that is committed with education. The spatial characterization of mathematical problems also demonstrates the importance of graphical representations in teaching not only mathematics and geography but also any other science, reinforcing the role of visualization in information representation and communication. From the results achieved, arising naturally needs and plans for further development in order to update the methodology.

\section{References}

[1] Gurevich, B. and Saushkin, Y.G. (1966) The Mathematical Method in Geography. Soviet Geography, 7, 3-35. http://dx.doi.org/10.1080/00385417.1966.10770844

[2] Fotheringham, A.S., Brunsdon, C. and Charlton, M. (2000) Quantitative Geography: Perspectives on Spatial Data Analysis. Sage.

[3] Johnson, B.A. (1968) The Use of Theoretical Models in Geography Teaching. Journal of Geography, 67, 237-240. http://dx.doi.org/10.1080/00221346808980934 
[4] Griffith, D.A. (2014) Reflections on the Current State of Spatial Statistics Education in the United States: 2014. Geo-Spatial Information Science, 17, 229-235.

http://dx.doi.org/10.1080/10095020.2014.986834

[5] Longley, P.A., Goodchild, M.F., Maguire, D.J. and Rhind, D.W. (2015) Geographic Information Science and Systems. John Wiley \& Sons, 560..

[6] Plummer, P. and Sheppard, E. (2006) Geography Matters: Agency, Structures and Dynamics at the Intersection of Economics and Geography. Journal of Economic Geography, 6, 619-637. http://dx.doi.org/10.1093/jeg/lbl005

[7] Barthélemy, M. (2011) Spatial Networks. Physics Reports, 499, 1-101. http://dx.doi.org/10.1016/j.physrep.2010.11.002

[8] Dogan, M. (1996) The Hybridization of Social Science Knowledge. Library Trends, 45, 296314.

[9] Adams, P.C. and Jansson, A. (2012) Communication Geography: A Bridge between Disciplines. Communication Theory, 22, 299-318. http://dx.doi.org/10.1111/j.1468-2885.2012.01406.x

[10] Bunge, W. (1966) Theoretical Geography. Vol. 1, Royal University of Lund, Department of Geography, Gleerup.

[11] Lima, A. and Musolesi, M. (2012) Spatial Dissemination Metrics for Location-Based Social Networks. Proceedings of the 2012 ACM Conference on Ubiquitous Computing, New York, September 2012, 972-979. http://dx.doi.org/10.1145/2370216.2370429

[12] Butler, D. (2006) Virtual Globes: The Web-Wide World. Nature, 439, 776-778. http://dx.doi.org/10.1038/439776a

[13] Cohn, A.G. (1996) Calculi for Qualitative Spatial Reasoning. International Conference on Artificial Intelligence and Symbolic Mathematical Computing, Berlin Heidelberg, 23-25 September 1996, 124-143. http://dx.doi.org/10.1007/3-540-61732-9_54

[14] Sheppard, E. (2001) Quantitative Geography: Representations, Practices, and Possibilities. Environment and Planning D: Society and Space, 19, 535-554. http://dx.doi.org/10.1068/d307

[15] Mesquita, E.A., Cruz, D. And Brito, M.L. (2016) Geoprocessamento Aplicado ao Mapeamento das Formas de Uso da Terra na Área de Preservação Permanente (APP) da Lagoa do Uruaú-Beberibe/CE. Revista Geonorte, 3, 1509-1518.

[16] Criado, R.C. and Piroli, E.L. (2016) Geoprocessamento como ferramenta para a análise do uso da terra em bacias hidrográficas. Revista Geonorte, 3, 1010-1021.

[17] Couclelis, H. (1999) Space, Time, Geography. Geographical Information Systems, 1, 29-38.

[18] Bishop, A.J. (1980) Spatial Abilities and Mathematics Education-A Review. Educational Studies in Mathematics, 11, 257-269. http://dx.doi.org/10.1007/BF00697739

[19] Laudares, S. (2014) Geotecnologia ao alcance de todos. Vol. 1, Appris, Curitiba.

[20] Berry, J.K. (2006) A Brief History and Probable Future of Geotechnology. BASIS, Fort Collins, Colorado.

[21] Dykes, J., MacEachren, A.M. and Kraak, M.-J. (2005) Exploring Geovisualization. Elsevier, Amsterdam.

[22] MacEachren, A.M., Gahegan, M., Pike, W., Brewer, I., Cai, G., Lengerich, E. and Hardistry, F. (2004) Geovisualization for Knowledge Construction and Decision Support. IEEE Computer Graphics and Applications, 24, 13-17. http://dx.doi.org/10.1109/MCG.2004.1255801

[23] Tomaszewski, B.M., Robinson, A.C., Weaver, C., Stryker, M. and MacEachren, A.M. (2007) GeoVisual Analytics and Crisis Management. Proceedings of the 4th International ISCRAM 
Conference, Delft, The Netherlands, May 2007, 173-179.

[24] White, J.J. and Roth, R.E. (2010) Twitterhitter: Geovisual Analytics for Harvesting Insight from Volunteered Geographic Information. Proceedings of Giscience, Zurich.

[25] Furner, J.M. and Kumar, D.D. (2007) The Mathematics and Science Integration Argument: A Stand for Teacher Education. Eurasia Journal of Mathematics, Science \& Technology Education, 3, 185-189.

[26] Alesheikh, A., Helali, H. and Behroz, H. (2002) Web GIS: Technologies and Its Applications. Symposium on Geospatial Theory, Processing and Applications, Vol. 15, Ottawa, 2012.

[27] Kraak, M.-J. (2004) The Role of the Map in a Web-GIS Environment. Journal of Geographical Systems, 6, 83-93. http://dx.doi.org/10.1007/s10109-004-0127-2

[28] MacInnes, J. (2012) Quantitative Methods Teaching in UK Higher Education: The State of the Field and How It Might Be Improved. University of Warwick, 21-22.

https://www.heacademy.ac.uk/system/files/quantitative_methods_teaching_in_uk_higher_e ducation_the_state_of_the_field_and_how_it_might_be_improved.docx

[29] Capel, H. and Sáez, H.C. (1985) Geografía humana y ciencias sociales. Editorial Montesinos.

[30] Laudares, J.B. (2004) A matemática e a estatística nos cursos de graduação da área tecnológica e gerencial: Um estudo de caso dos cursos da puc minas. In: Cury, H. (Org.), Disciplinas Matemáticas em cursos superiores: reflexóes, relatos, propostas, EDIPUCRS, Porto Alegre.

[31] 3Geolink (2015) Web Map Target Antennas Using Angles and Distances. http://www.3geolink.com/prodemge/angles.html

[32] 3Geolink (2015) Telecommunications Network Planning Web Map. http://www.3geolink.com/prodemge/altimetry.html

[33] GOOGLE (2016) Google My Maps.

https://support.google.com/mymaps/answer/3024396?hl=en\&ref_topic=3188329

\section{Submit or recommend next manuscript to SCIRP and we will provide best service for you:}

Accepting pre-submission inquiries through Email, Facebook, LinkedIn, Twitter, etc.

A wide selection of journals (inclusive of 9 subjects, more than 200 journals)

Providing 24-hour high-quality service

User-friendly online submission system

Fair and swift peer-review system

Efficient typesetting and proofreading procedure

Display of the result of downloads and visits, as well as the number of cited articles

Maximum dissemination of your research work

Submit your manuscript at: http://papersubmission.scirp.org/

Or contact jgis@scirp.org 